\title{
THE FIREHOUSE OF FALSEHOOD OF RATNA SARUMPAET'S HOAX IN MEDIA FRAME
}

\author{
Bellinda Putri Ervitasari, Basuki Agus Suparno \\ Department of Communication Science \\ Faculty of Social and Political Sciences UPN "Veteran" Yogyakarta \\ Email: belindaptr@gmail.com
}

\begin{abstract}
Hoax often appears with massive political momentum, such as the atmosphere of the Presidential Election campaign. Its appearance is often related to other issues and can lead to confrontations on social media such as hatred, blasphemy, and humiliation. On October 2, 2018, the news of Ratna Sarumpaet being persecuted appeared on the internet. It was linked to imposing another camp after her several political colleagues echoed the report everywhere. It didn't take a long time for the police officer to uncover the truth, which turned out to be a hoax. The formulation of this research problem is how Detik.com's online news portal frames, selects, and highlights the news about hoax cases created by Ratna Sarumpaet. This study aims to determine the 1) syntactic structure of the online news portal Detik.com through the hoax case about Ratna Sarumpaet, 2) to know how journalists tell the facts (scripts) used by Detik.com by referring to their vision and mission in emphasizing hoax about Ratna Sarumpaet, 3) to understand the thematic structure by identifying the involvement of Detik.com media in reporting hoax cases of Ratna Sarumpaet, and 4) to find out the rhetorical structure by emphasizing the fact in the case of Ratna Sarumpaet's hoax. The researcher used a qualitative research method, with data collection techniques through online media data tracking techniques and by reviewing documents and archives. The analysis theory used was the framing analysis by Zhongdang Pan and Gerald M. Kosicki. This research indicates that Detik.com focuses more on high site traffic and a massive amount of visitors or readers. The profit from the income received can maintain good relations between the company and the stakeholders.
\end{abstract}

Keyword: Framing, Online Media, Hoax, Ratna Sarumpaet

\section{INTRODUCTION}

Hoax is information that is engineered to cover up real information. A hoax can also be interpreted as an act of obscuring the actual report by flooding a media with the wrong message to cover the correct news. The purpose of an intentional hoax is to make people feel insecure, uncomfortable, and confused. In confusion, people will make weak, inconclusive, and even wrong decisions. The development of hoax on social media was originally carried out for means of shielding. However, political spin doctors see hoaxes' effectiveness as a black campaign tool in a democratic party that influences voters' perception as hoaxes is information engineered to cover up real information. A hoax can also be interpreted to obscure the essential information by flooding a media with a wrong message to cover the correct news. The purpose of an intentional hoax is to make people feel insecure, uncomfortable, and confused. In confusion, people will make weak, inconclusive, and 
even wrong decisions. The development of hoax on social media was originally carried out for means of shielding. However, further products, political spin doctors see the effectiveness of hoax as a black campaign tool in a democratic party that influences the perception of voters (Mendidik, 2016)

Ratna Sarumpaet, a human rights activist who started her career from the world of drama and theater, made a public scene on Tuesday $(2 / 10 / 18)$. The news that Ratna experienced a meltdown due to being persecuted by certain elements blew in various media. The day after the alleged spread, Ratna Sarumpaet admitted that she had lied and said she was the creator of the best hoax.

The emergence of the hoax phenomenon often coincides with the significant political momentum like that at the campaign atmosphere ahead of the 2019 presidential election. Its appearance is often related to other issues that can trigger confrontation on social media such as hate speech, mutual blasphemy, and condescension. There was no exception with Ratna Sarumpaet, who was linked as an attempt to bring down one of the camps.

This furor started because news of Ratna's persecution was echoed by a deputy of one of the presidential and vicepresidential pairs, namely Prabowo Subianto-Sandiaga Uno. They even had a press conference that strongly condemned the persecutors. Ratna's background, known as someone who was very vocal in voicing criticism of the government, was also predicted to be the trigger for the persecution. This logic is quite reasonable, and the accusations can be easily directed at the government as a form of silencing an activist. However, after the truth was revealed, many people later speculated that this event aimed to gain public sympathy. Therefore, through framing analysis, researchers want to dissect media methods or ideologies when constructing the facts in the case of Ratna Sarumpaet. The researcher will look at the selection strategies and prominence of journalists to find out how the role of journalists in leading public interpretations.

He took Detik.com as a research medium because Detik.com was the most popular online news site and was most accessed by Indonesian people, according to the Alexa Top Sites in 2018 (Alexa, n.d.). The site places Detik.com in the first rank based on high traffic (access). For this reason, further discussion and research, namely by analyzing the Detik.com frame in covering, writing, and presenting news of the Ratna Sarumpaet hoax case, is fascinating to do.

Based on the description above, two problem statements can be drawn: 1) how Detik.com's online news portal frames 
news about hoax cases conducted by Ratna Sarumpaet and 2) how Detik.com's online news portal selects and highlights information about hoax cases carried out by Ratna Sarumpaet. While this study aims to 1) find out the syntactic structure of online news portal detik.com through news writing on hoax Ratna Sarumpaet cases, 2) find out how journalists tell the facts (scripts) used by Detik.com by referring to their vision and mission in emphasizing hoax cases Ratna Sarumpaet, 3) know the thematic structure, by identifying the extent of the involvement of Detik.com media in reporting the issues of hoax Ratna Sarumpaet and 4) to find out the rhetorical structure by emphasizing the experiences in the case of hoax Ratna Sarumpaet.

The supporting theoretical framework for this research is social media construction and framing analysis. Mass media social construction is taken from the approach of social construction theory Peter L. Berger and Thomas Luckman by looking at phenomena in externalization, objectivation, and internalization. According to this perspective, the stages in mass media social construction occur by preparing construction materials, distributing structure, the construction phase, and the confirmation stage (Bungin, 2007). Explained as follows: 1) Stage of preparing construction material. There are three important things at this stage: the alignment of the mass media to capitalism, the apparent partiality of the community, and partiality to the public interest. 2) Stage of construction distribution. The distribution of mass media construction is carried out through mass media strategies. The basic principle of mass media social structure distribution is that all information must reach the audience appropriately based on the media plan. What is considered necessary by the media is also crucial for the readers. 3) Stage of formation of reality construction. The construction takes place through three things, including the construction of the reality of justification, willingness to be constructed by the mass media, and consumptive choice. 4) Confirmation stage. Confirmation is when the mass media and the reader give arguments and accountability to their intentions to be involved in the formation of construction.

While simple framing analysis can be described as an analysis to determine how the media frame reality (events, actors, groups, or whatever). The framing is, of course, through the construction process. Here the social fact is interpreted and constructed with specific meanings. Certain formations understand events. As a result, media coverage on sure sides or interviews with certain people. All these elements are technical journalism sections and indicate 
how events are interpreted and displayed (Eriyanto, 2009).

\section{METHOD}

This study's type of research is qualitative research with Zhongdang Pan and Kosicki framing analysis methods. This study's object is the contents of the news contained in Detik.com's online news portal, October 2 - 5, 2018, regarding the hoax case conducted by Ratna Sarumpaet. Data collection techniques using data search techniques through online media and data analysis techniques that researchers use are data analysis using text analysis. The research was conducted over the past six months, using an extension of observation, increased perseverance, and discussion with colleagues to examine the study's validity.

\section{DISCUSSION}

From the observation of the Pan and Kosicki framing device, some crucial points can be drawn that can be examined about how Detik.com constructed the hoax case of Ratna Sarumpaet.

Judging from the 16 news studied's syntactic structure, in choosing the title Detik.com tended to take from the direct quote from the resource person who also described the contents of the information. Not finished there, Detik.com also tends to make sensational titles and can attract readers' interest. Through the label he made, Detik.com intends to bring readers' thoughts to the subject matter discussed in the news agency. After the analysis process, ten news was found with titles that used the informant's statement quotation. One example is the second news entitled "PD Berang Ratna Sarumpaet Dianiaya: Masa Nenek-nenek Dipukuli!". In addition to quoting the informant's statement, in writing the headline, Detik.com also tends to choose provocative statements that can attract audiences to read by exploiting the curiosity gap's human cognitive side.

Furthermore, most of the Detik.com news tended only to use one source. There is also some news with more than one source, but Detik.com puts the second speaker's opinion on the closing statement so that the second speaker does not have the same opportunity and space to speak as the first speaker. It causes the news content from Detik.com to be less balanced or not to cover both sides. It would be better if the news presented views had more than one side of the idea not to cause overlapping in the report's presentation. Also, of the 16 stories observed by researchers, Detik.com looks less varied in selecting and selecting its speakers. The researcher found that Fadli Zon was a resource from 7 news among the 16 reports. The portion is large enough to question the balance and partiality of 
Detik.com in its reporting. The name makes the news; that's about Detik.com's attitude in reporting the hoax case of Ratna Sarumpaet. Fadli Zon is one of the other sources whose behavior can be news that attracts others' attention because of their controversial opinions.

If it is explored further, within four days, in the span of the reporting period 25 October 2018, Detik.com contains 467 news about the hoax case of Ratna Sarumpaet. As long as this case is rolling and keeps grazing on big names, Detik.com is increasingly reporting it. The high intensity of this news can be very potential to shape public opinion. An enormous media power is considered to form an audience to have the same perception of a case. Compared to the news's balance and accuracy, Detik.com seems to prioritize information speed to pursue massive traffic. Here, the news's momentum appears to be an absolute thing, along with the formula of bad news is good news; Detik.com seeks upload speed and intensity to get the most traffic. Also, if massive traffic is reached, this may be the main attraction for advertisers. News verification and balance on the cyber media news guidelines that have been ratified by the Press Council and the Press Community in Jakarta on February 3, 2012, explain how online media must behave even when it is speeding up news. The points are as follows:

a. In principle, every news must go through a verification process.

b. News that can harm other parties requires verification on the same news to fulfill the principle of accuracy and balance.

c. The provisions in point (a) above are excluded, with the following conditions: 1) News contains urgent public interests 2) The first news source is a source that is clearly identified, credible and competent 3) News subjects that must be confirmed are unknown and or cannot be interviewed 4) The media explained to the reader that the news still needed further verification which was attempted as soon as possible. The explanation is included at the end of the same report, in parentheses, and using italics.

d. After loading the news by item (c), the media is obliged to continue verification efforts. After verification is obtained, the verification 
results are included in the update news with a link on information that has not been verified (Pers, n.d.)

These guidelines do not turn off the advantages of Detik.com and other online media in the speed of news. They are given away to "suspend" the obligation to verify and balance an explanatory note at the end of the news. However, after paying attention to the information with one source published by Detik.com, Detik.com has not carried out its obligations as stated in the guidelines above. In this case, Detik.com looks negligent.

While on the script structure, the news is examined based on the $5 \mathrm{~W}+1 \mathrm{H}$ elements (what, where, when, why, who, and how). Of the 16news observed by researchers, some news items do not meet journalistic rules where one element of $5 \mathrm{~W}$ $+1 \mathrm{H}$ is not contained in the news content. An example can be seen in news 6 with the title "Polisi akan Periksa Ratna Sarumpaet." In the news, there was no element of why. Meanwhile, the use of coherence is found in the report analyzed by researchers. Coherence is a link between words, propositions, or sentences. Coherence is useful for connecting two sentences or propositions with different facts, so even unrelated facts can be related (Eriyanto, 2009). In the news that the researchers analyzed, it was found explanatory coherence and causal coherence.

The use of rhetorical aspects is also found in the news that has been analyzed by researchers. The use of words, idioms, pictures/photos, and graphics are used to better support or strengthen news content. For example, this is indicated by the phrase "Pakai Otak!" on the news entitled "Dilaporkan ke MKD, Fadli: Etika Mana yang Dilanggar, Pakai Otak!"”. The word is used to describe a difficult situation. While the existing graphics do not affect the news in terms of graphics, Detik.com only displays photos from news sources.

The four structures used to analyze the news in this study are related to one another. The syntactic structure about the title, lead, background information, quotations from sources, and conclusions are interconnected with script structures that analyze the completeness of $5 \mathrm{~W}+1 \mathrm{H}$ elements, whereinto analyze $5 \mathrm{~W}+1 \mathrm{H}$ components, the results of the analysis of syntactic structures need to be known first. The existence of thematic and rhetorical structures then complements the two previous structures where thematic contains coherence, which serves to combine sentences and rhetorical forms that emphasize the use of graphics and other news supporters.

After looking at the analysis results using the four framing devices, it can be 
seen that a media has a particular perspective on seeing events. The point of view will ultimately reflect the media's alignments in producing the news and poured in by following the stages of the construction process of the mass media reality. According to Bungin (Bungin, 2007), the step is preparing construction materials, the construction stage, the construction phase, and the confirmation stage.

At the stage of preparing construction material, it can be seen that Detik.com has an implicit nature in this reporting, but on the one hand, it was also found that Detik.com tried to provide news that could attract readers so that it was profitable for them. This was reflected in journalist Detik.com who continuously provided a report with a title that invited the 'curiosity gap' from its readers. Some titles also seem to discredit certain parties; that impression is also supported by data that has been collected in the field and selects speakers who can establish and represent Detik.com's opinion.

Next is the stage of the distribution of construction carried out by Detik.com during the news. As long as this case is rolling, Detik.com is very keen to report on the topic of Ratna Sarumpaet. Informing reality construction, besides using speakers from authorities who have competence in their fields, Detik.com also tends to choose speakers who can be news ammunition. These, namely important figures, have news value in prominence and fame in the same frame. The existence of opinions from speakers who have this news value is allegedly able to attract readers.

Next is the construction phase of the construction that Detik.com constructs by looking at how the reader addresses the news. First, namely the structure of the reality of justification as a form of mass media construction formed in society. Society tends to justify anything that is (presented) in the mass media as a reality of truth. Second, the mass media's willingness to be constructed, namely the generic attitude of the first stage above. That being a reader of mass media is the choice of each reader to be willing to have his mind constructed by the mass media. Third, making mass media consumption a consumptive choice, where one is accustomed to relying on mass media so that mass media is a habit that cannot be released.

The last is the confirmation stage constructed by Detik.com by giving its argument as mass media. Detik.com's involvement in providing its opinions is reflected in Detik.com's statement on the news 15 paragraph 12, "Then, the drama became a 'snowball," where the argument explained that Detik.com saw the case of Ratna as a drama that increasingly 
significant because of dragging important figures.

Detik.com has a distance between reality and the construction of reality in terms of the media's existence. It is indicated by the selection of speakers, most of whom came from only one side, likewise, in selecting words and coherence used in the news, reflecting the attitude of journalists who seem indifferent and rely solely on statements from resource persons.

It is not in harmony with the construction of reality that the media should do. The media composes the truth of various events that occur to become meaningful stories or discourses. Making news in the media is an effort to compile realities to form meaningful information and discourse as expected. Thus, the media's entire content is a reality that has been constructed in the form of meaningful discourse (Hamad, 2004).

Meanwhile, when viewed from the side of online journalism, Detik.com, as one of the principal online media portals in Indonesia, has provided various information needed by the audience at all times. It is like in online media characteristics, where one of them is the speed of information delivery (immediacy).

Through the 16 news samples above, it can be seen that in its news, Detik.com continuously presents a hyperlink containing further information, archives, sources, and data that can be accessed at any time. For example, in the news text entitled "PD Berang Ratna Sarumpaet Dianiaya: Masa Nenek-nenek Dipukuli!". Two hyperlinks were presented (Timses Jokowi Dorong Polisi Usut Kasus Penganiayaan Ratna Sarumpaet and Fadli Zon Jenguk Ratna Sarumpaet, Begini Kondisinya) it shows Detik.com has met the characteristics of online journalism in terms of hypertextuality.

Furthermore, Shoemaker and Reese (Sobur, 2009) explained hierarchical factors that influence media content, namely individual factors, media routine factors, organizational factors, and extra media.

\section{Individual Factors}

This factor relates to the professional background of the media manager. The individuallevel looks at how the influence of the media manager's aspects influences the public's news. As a person who is directly faced with a reality in the field, individual journalists have their point of view in seeing subjective and balanced information, but there are still individual elements that influence the work of journalists. 
Journalist principles also

influence the workings of a journalist in adhering to the journalistic code of ethics. This ethical code factor binds a journalist to carry out his work to find news. Referring to CyberMedia News Guidelines, news on cyber media must go through a verification process and prioritize accuracy and balance principles. Based on the journalist's findings, Detik.com researchers have not carried out the verification obligations as written in the guidelines above. In the 16 news that was the object of this research, several titles used the source's direct quote as the title covered by different journalists. In this level, Detik.com reporters certainly have their way of looking at the reality in the field relating to Ratna Sarumpaet's hoax case. Therefore, after the analysis process, it appears that journalists tend to link Ratna's persecution cases with political issues because, since the beginning of the news, the hoax case of Ratna Sarumpaet was herded into a political cause by raising topics related to politics.
2. Media Routine Factors

A journalist's view of what objectivity is, news sources will be formed based on the media routines where the journalist works. Factors in media routines relate to the mechanism and process of determining news. This media routine also refers to how information is formed.

Detik.com, as online media, does not go through the stages as print media do. That is because online media prioritizes speed in updating information to not go through the work sequence as conventional media do. For this reason, online media need to update information continuously on a topic so that the news delivered to the public remains accurate even though not through editorial mechanisms in general.

\section{Media Organization Factors}

In media organizations, each organization must have a purpose that affects the content of the news. Detik.com is part of Trans Corp led by Chairul Tanjung.

Detik.com management makes policies and objectives of the company. The 
procedures and goals in the organization indirectly affect Detik.com's view of seeing an event.

That Chairul Tanjung is known as the owner of the Detik.com media network is a non-party figure. He was careful so that his business empire was not disturbed by political issues surrounding him. "Chairul Tanjung's caliber (Chairman of CT Corp) and Basrizal Koto (Basko Group CEO) were able to position themselves as conglomerates today not to start their careers as politicians at a young age. Instead of busy forming a party, CT, Chairul Tanjung's nickname, was instead hunted by many parties, both as the advisory board, the main functionary, and the presidential candidate. However, CT is unmatched with its consistency as a 24-carat entrepreneur" (Kumparan, 2018, accessed April 20, 2019). In the online media Kumparan above, Chairul Tanjung as the Detik.com network owner, is known as a non-political figure who prioritizes business, so Chairul's position is considered neutral and has no tendency one of the political camps. The statement that Chairul was cautious because he paid attention to his businesses reinforced that Chairul as the leader of Detik.com, influenced Detik.com's goal in presenting news, namely news that was able to attract readers and advertisers that they could benefit and attract profits for Seconds.

Kumparan also still has continuity with Detik.com because also founded by the founders of Detik.com, namely Budiono Darsono, Abdul Rahman, and former Detik.com employees, including Hugo Diba (CEO), Ine Yordenaya (COO), Heru Tjatur (CTO), Arifin Asydhad (Editor in Chief), and Yusuf Arifin (Chief of Engagement).

\section{Extra Media Factors}

This factor explains the factors outside the media that influence the process of news production. These factors can come from various things: state (country), market (market), and the public. The state is the existing government or those in power in 
a country can influence the news content. The media market is seen from two aspects, first sales, the second comes from advertising. The number of people who advertise on the media indicates that the audience widely enjoys the media.

The influence of extra media is very influential because journalists cannot write the news in writing a story if no news source can provide information and information regarding the report. Readers and advertisers are also essential because both finance the production, by Detik.com's mission of delivering optimal sustainable results for shareholders. So that at this level, it can be seen when presenting the news, Detik.com focuses on pursuing the intensity of the information so that it can capture large traffic so that the profits obtained are also high.

5. Ideological factors

The ideology adopted by mass media institutions usually affects the contents of the content presented by the media.
According to Shoemaker and Reese, ideology is an integrated frame of mind regarding how we see the world and hopes for others to adjust to our actions. Like Detik.com, the content he made is a reflection of the ideology adopted by Detik itself.

In the general description of the research object, it is stated that Detik.com's vision is to become the primary goal of Indonesian people to get digital content and services, both through the internet and cellular/mobile. At the same time, the mission aimed at Detik is to have a high commitment to provide satisfaction to customers, provide welfare to employees, become the right place for a career, and provide optimal sustainable results for shareholders. This concept later became the foundation of Detik.com in presenting the news.

Points to provide sustainable optimal results for shareholders explain that Detik.com runs its business inseparable from seeking as much profit as possible for the company and 
shareholders. It might underlie Detik.com's attitude that prioritizes the news's speed and intensity so that the site's traffic is high, the visitors are many, and readers are crowded. Traffic affects income, as well as sales and advertisements in print media.

\section{CONCLUSION}

Based on the research, the first finding on the online news media frame of Detik.com shows that in constructing the facts in Ratna Sarumpaet, Detik.com framed this hoax case as a political case. It was concluded that because of the syntactic structure that had been carried out to observe each news since the beginning of the information, Detik.com tended to take sources from Ratna's closest colleagues. They were in the same political coalition as Ratna. In fact, out of the 16 news, not one news was found with sources coming from Ratna's family or lawyer Ratna Sarumpaet. The conclusion was also obtained from the thematic structure Detik.com explained through paragraphs, sentence propositions, and the inter-sentence relations that Detik.com assembled in reporting the hoax case of Ratna Sarumpaet tended to be constructed towards politics.
The second finding is seen from how Detik.com selects and highlights the reporting of hoax Ratna cases in rhetorical structure, namely the way journalists emphasize facts. At the beginning of the news, before the fact that what Ratna said was only a hoax, Detik.com tended to defend Ratna by underlying sympathy and humanity. Detik.com also highlighted Sandiaga's opinion about Ratna's status as an activist whose aspirations often clashed with the government (news 3), so Detik.com seemed to lead readers' views that the perpetrators of the persecution of Ratna were from the side who often clashed with her aspirations. However, after the fact that the persecution was only a hoax was revealed, Detik.com focused on the people who had voiced Ratna's hoax. It indicates that Detik.com focuses more on high site traffic and a considerable amount of visitors or readers. The profit from the income received can maintain good relations between the company and the stakeholders.

The third finding, Detik.com looks negligent about the obligation to verify and balance the news. Detik has not carried out its responsibilities as written in the CyberMedia News Guidelines. It is evidenced by the fact that there is only one source in some news, and there is no verification and confirmation effort written on the story. 


\section{REFERENCE}

Alexa. (n.d.). Alexa. Retrieved from Alexa: https://www.alexa.com/topsites/cat egory/World/Bahasa_Indonesia/Be rita/Online

Bungin, B. (2007). Metode Penelitian Kualitatif. Jakarta: PT. Raja Grafindo Persada.

Eriyanto. (2009). Analisis Framing: Konstruksi, Ideologi, dan Politik Media. Yogyakarta: LKiS.

Hamad, I. (2004). Konstruksi Realitas Politik dalam Media Massa. Jakarta: Granit.
Mendidik, I. (2016). Indonesia Mendidik. Retrieved from Indonesia Mendidik:

http://indonesiamendidik.com/tag/a nti-hoax

Pers, D. (n.d.). Pedoman. Retrieved from Dewan Pers: https://dewanpers.or.id/kebijakan/p edoman

Sobur, A. (2009). Analisis Teks Media: Suatu Pengantar untuk Analisis Wacana, Analisis Semiotik, dan Analisis Framing. Bandung: PT. Remaja Rosdakarya. 